\title{
Professional-Database and Staff-Appraisal as Correlates of Principals' Performance in Public Secondary Schools in Delta State, Nigeria
}

\author{
EBUNU, Akpofure. Anna \\ Nigeria \\ *Corresponding Author: EBUNU, Akpofure. Anna, Nigeria

\begin{abstract}
This study examined professional database and staff appraisal as correlates of principals' performance in public secondary schools in Delta State. Two research questions guided the study. Two hypotheses were also tested in the study at 0.05 significant level. The study adopted the correlation design. The study population was the 427 principals in public secondary schools in Delta State Post-Primary Education Board. The sample size was 342 principals serving in public secondary schools in Delta State. The multistage sampling technique was used to select the sample. The instruments used to generate data were two questionnaires, a professional database, staff appraisal and principal performance with reliability coefficients of 0.96 and $0.89(P D S A Q)$ and (PPQ). The generated data were analyzed using Pearson $r$ and simple regression, $t$-test associated with simple regression. The findings of the study revealed that the professional database and staff appraisal respectively had a positive and moderate relationship with principals' performance. The study further revealed that professional database and staff appraisal were significantly related to principals' performance in public secondary schools in Delta State. The recommendations made included principals should learn how to keep records of their colleagues, experts, and subordinates to enable them (principals) to track their co-workers and learning partners for work-related communication.The study also recommended that the Ministry of Education regularly appraise principals' performanceto enable them
\end{abstract} \\ to learn from reputable experts and improve their performance in school administration.
}

\section{INTRODUCTION}

Today's schools operate in a dynamic and rapidly changing environment in which school administrators must adapt and function as change agents to maintain high performance in school administration. TheSchools are confronted by rising pressure from parents and the public to improve teaching and learning experiences to help learners become useful to citizens.The role of school principals has only increased to include the responsibility of leading teaching and learning in a technology-driven learning environment in which learners are at the centre of instructional objectives. The principal can make a spectacular difference to achieve educational goals through an adequate performance of administrative functions. Performance in this context is the act of accomplishing a given task so properly that the intended objectives are achieved successfully and satisfactorily (Ion \&Criveanu 2016:179).Samsonwa (2010:10) defined performance as a process of executing a specific work to achieve intended results. Performance is mostly positively associated with effectiveness and efficiency, which respectively entail goal attainment concerning the quality and quantity of resources expended to attain the set goal.

The preceding suggests that performance is relative and implies that it can be positive or negative, which means that a given task can be performed poorly, satisfactorily, or excellently. If that is true, then poor task execution is a bad performance. If bad performance is possible, then good or excellent performance is also possible. The difference between the degree or quality of performance arises mainly from the quality of knowledge or the skills the performer has that enable him/her to perform something effectively or poorly. This suggests that experience and employee-motivation are just moderators of performance as knowledge and expertise are crucial determiners of performance. Therefore, principal performance can be defined as the degree to which a school principal uses school 
resources to accomplish secondary education goals in a particular secondary school (Akhta\& Cheema, 2014:25).

As the school leader, the principal has the responsibility of setting time-specific targets and goals for the school, mobilizing human and material resources towards attaining set goals. The vital role of a school principal is to ensure that teaching and learning in the school are appropriately coordinated and effectively carried out by teachers. Determining the standards for measuring principals' performance is a bit tricky, given that the existential disagreement over whether to conceptualized performance based on the behaviour of the principal or the outcome of such behaviour has not been resolved. Nevertheless, Ivanov and Avasilca (2013) asserted that outcome-based principals' performance measurement is more realistic as it employs input-output parameters in assessments. O'Donnell and Duffy (2002:3-4) argued that using behaviour-based measurement procedures is more effective, less ideological, and more practical, adding that such an approach helps managers identify desirable workbehaviours and thus influence employees accordingly. These discrepancies often lead to confusion in conceptualizing and measuring performance.

It is necessary to identify the relevant work-behaviours that conduce to or strengthens the attainment of set goals. Ion and Criveanu (2016:179) observed that performance is measurable by gauging effectiveness, efficiency, quality of goal attainment, productivity, quality of product/services, profitability, adaptability, risk management, and sustainability. In this respect process of personnel management, instructional leadership, supervision, and other functional responsibilities associated with the school principal's positionare regarded as behaviour-based measures of principals' performance.On the other hand, the standard of education iscriticalto administration, teachers' jobperformance, students' discipline, administrative accountability, and students' achievement are outcome-based measures of principals' performance.

In this light, principals' performance can be measured by examining the extent to which their behaviours and resulting outcomes lead to effective school administration, discipline and peaceful school climate, practical teaching and learning, improved students' learning outcomes. To perform their administrative functions well, principals have to build an interpersonal relationship with their subordinates by visiting them at their respective duty posts and connecting them to build trust and rapport necessary for effective instructional leadership. The proper performance of school principals' functions is crucial to attaining predetermined goals. Therefore, it needs to be accorded maximal attention to realize the intended improvement in students' achievement. However, principals who lack relevant work performance abilities to administer schools effectively will be limited, and their performance will be most likely poor. This is why school principals have to regularly improve their administrative skills and managerial competencies to ensure that their school leadership strategies are not obsolete. Asodike and Ogbu (2014:102-103) observed that school principals could enhance their administrative skills and knowledge through staff-appraisal. This agrees with Padzil et al. (2019:41), who corroborated the above scholars and added that keeping a professional database is another key method principals use to sharpen their professional networking strategy.

Professional database (PD) is a new term; it is a contact building activity and management of information related to relevant individuals and associated professional affiliations in sequential order that permit easy retrieval and utilization when needed (Whittaker et al., 2002:2). The desire to excel as an educator begins with an individual educator. It starts with taking the initiative to identify one's career purpose, choice, interest, and then compiling the details of people and related professional organizations one knows and arranging such information in an organized, professional database. This involves researching people and organizations involved in a similar line of work whose professional experiences and accomplishments could be of significant benefit to one's career progression. One of the purposes of keeping a professional database is for easy access to details of professional colleagues to reach out to them to consolidate and expand one's networks and knowledge through connection to colleagues via phone calls, messages, and emails. In this way, newly appointed or mid-level principals can expedite their career advancement by joining professional associations and learning communities. They can also sign-up on social media sites, attend events and academic retreats, read professional journals, participate in seminars and other educational gatherings that attract expert discussants in topical issues of interest in education. 
A professional database (PD) may be used for different reasons. For instance, it readily provides information about colleagues, associates, friends, and other professionals. Such information is necessary for regular communication and bonding. Apart from using professional contact to prospect for better jobs and consultations, PD can also help principals quickly retrieve information about a colleague whom one desires to reach through calls to express good wishes, compliments, and felicitation networking strategies. Principals can also use their database to reach out to knowledgeable school managers/administrators to discuss the particular administrative issue of concern.Perhaps make pre-arrangement for the meeting during which robust interaction between them is expected to result in more significant insights over the managerial issue of concern (Etomeset al., 2017:243).

However, before embarking on any such professional meetings, one must use the database to update the person one wants to meet.Draft how the conversation should go and be open-minded and ready to learn or listen to whatever information or knowledge may emerge from the meeting through interaction. Such meetings and subsequent regular work-related conversations may both lead to mentorship and deepened relationships which the principals can leverage to learn new skills and unknown management practices in education. (Darling-Hammond et al. 2009:5). Gregoire (2009:4) remarked that the quality of the personal relationship between people of significant value within and outside professional circles determines a large extent to reach in the professional hierarchy.

Principals may use such interactive opportunities to explain his/her managerial philosophy, practices, and specific workplace experiences for the critique and inputs of the veteran educator. Such joint reflection and discussions usually open different administrative areas (such as teacher motivation strategies and other aspects) that may in diverse ways benefit the school principal (Green, 2009). Etomes and Molua (2019:50) observed that educators will always need external support, arguing that their experiences and capacities may not be enough to match the level of improvement the school aspires to attain. Hence, they need to expand their professional database and acquaintances to build social capital and network muscles that one can leverage during professional needs.

Staff-appraisal is an essential professional networking tool education managers can use to enhance educators' professional growth and performance (Asuku\& Abraham, 2019:536). An appraisal is traditionally used to refer to a formal assessment of an employee, focusing on ascertaining a value judgment over an employee's work-related activities in the recent past. Asodike and Ogbu (2014:102103) defined appraisal as a process of upgrading teaching and learning in school through a procedural evaluation of staff performances by reviewing and carefully examining their past work-performances to help such employees to perform their duties professionally and excellently. Organization for Economic Cooperation and Development (OECD) (2013:492) opined that principal appraisal is an evaluation process in which external assessors (usually from the board) seek to determine the 'strengths and weakness'of school principals using standardized criteria prepared for making judgment concerning their work performance-abilities as it affects school leadership, management, and employment cum promotion-related matters.

This implies that appraisal embraces both assessments of competencies, improvement of performance abilities, and recruitment evaluation, covering probational and promotional assessment processes, which may, in this view, involve vice-principals. In this view, an appraisal can be considered as a support-driven assessment of principals' work-related activities to make a value judgment about their work performance strengths and weaknesses to provide appropriate guidance and advice. In other words, the appraisal is essentially supportiveof building principals' capacities for higher performance in carrying out school administration. Staff-appraisal offers principals meaningful opportunities for expert and self-evaluation geared towards improving school leaders' work performance skills, thus serving as a way of fostering instructional effectiveness and performance accountability in school administration.

In this view, staff-appraisal may be designed to evaluate the personality-related performance of the principal (in which the traits of the principal being appraised are evaluated in connection with work performance) (Gudyzanga et al., 2014:464). The scholars also observed that staff-appraisal might also be result-based performance appraisal (which focuses on outputs of the appraisee). According to the scholars, staff-appraisal may also be geared towards work-behaviour performance assessment (which focuses on the appraisee's work performance processes and procedures), despite the diversity of approaches and purposes underpinning appraisals in school.Be it principal's appraisal, vice-principals 
appraisal, or teachers' appraisal, there seem to be common features and embedded advantage that mark credence to the existential coexistence of the approaches towards enhancing school employees' capacities.

Strong (2013:3) asserted that evaluating the performance of school leaders (or any school employee) improves the effectiveness of teaching and learning and general school performance. If school administrators must champion national goals on secondary education, a look into their activities is a necessary pathway that will provide useful information necessary to support them. Objective feedbacks, for instance, afford principals the necessary information about their deficiencies so that they can learn and grow professionally (Nielsen, 2018:4). Aloo et al. (2017) reported a strong and positive relationship between the appraisal programme and educators' performance. This corroborates the assertions of Clifford et al.(2014:5). They observed that feedback such as value-judgment, objective criticism, encouragement, and counsels are some of the contents of appraisal 'feedback document' prepared by external appraisers that help principals identify their weaknesses, strengths, and task areas to improve their skills for higher performance.Professional-database and staff-appraisal have been heightened as useful strategies for enhancing principals'performance.However, the extent to which these professional networking approaches have been improving principals' performance in the context of secondary schools in Delta State was largely not researched, hence this study.

\section{Statement of the Problem}

It isestablished that principals contribute significantlyto the success of secondary education. This is because they playa vitalrole in the coordination of effective teaching and learning in schools. Without a doubt, their performance determines, to a large extent, the productivity of teachers, and by extension, the academic achievement of students. However,anecdotal observation of the researcher indicates that a sizable number of secondary school principals in Delta State are eithernot taking their jobs seriously or do not have the requisite skills to manage their respective schools effectively.Some principals are deficient in administrative skills to manage their subordinates properly. Some teachers absent themselves from school without permission, come to school late, lessen notes, are poorly prepared, and exhibit different forms of negative work-behaviours without adequate administrative checks curtail such misconducts. Could it be possible that principals of the affected schools do not have adequate administrative skills required to coordinate school affairs, manage staff properly and enforce discipline?

There is no doubt that if these problems continue, the declining academic performance of students (as evident by a massive failure of students in 2018/2019 SSCE) will get worse, and the goals of secondary education may never be achieved.To understand and find a lasting solution to these problems, this study sought to determine if maintaining professional-database and appraising principals regularly could help to improvetheir performances in school administration.

\section{AIM AND OBJECTIVES OF THE STUDY}

This study aimed to determine the relationship between professional-database, staff-appraisal, and principals' performance in public secondary schools in Delta State. Specifically, the objectives of the study were to;

1. determine the relationship between professional database and principals' performance in public secondary schools in Delta State.

2. ascertain the relationship between staff-appraisal and principals' performance in public secondary schools in Delta State.

\section{RESEARCH QUESTIONS}

The following research questions guided this study;

1. What is the relationship between professional database and principals' performance in public secondary schools in Delta State?

2. What is the relationship between staff-appraisal and principals' performance in public secondary schools in Delta State?

\section{HYPOTHESES}

The following null hypotheses tested at 0.05 alpha level guided the study. 
1. There is no significant relationship between professional database and principals' performance in public secondary schools in Delta State.

2. There is no significant relationship between staff-appraisal and principals' performance in public secondary schools in Delta State.

\section{Methodology}

The study adopted the correlation design. The study population was the 427 principals in public secondary schools in Delta State Post-Primary Education Board. The sample size was 342 principals serving in public secondary schools in Delta State. The multistage sampling technique was used to select the sample. The principals were grouped into eleven (11) strata, in line with the eleven (11) education zones. Each stratum's proportion to the population was used to determine how many principals were selected from each stratum. Two instruments were used in this study, namely "Professional-database, Staff-appraisal Questionnaire" (PDSAQ) and "Principals' Performance Questionnaire" (PPQ).The reliability test of the instruments yielded coefficients of 0.95 and 0.89 for PDSAQand PPO, respectively. The data generated with the two instruments were analyzed using Pearson $r$ and simple regression, $t$-test associated with simple regression.

\section{DATA ANALYSIS AND RESUlTS}

Research Question One: What is the relationship between professional database and principals' performance in public secondary schools in Delta State?

Table1. Simple regression analysis on the extent of the relationship between professional database and principal performance in public secondary schools

\begin{tabular}{|l|l|l|l|l|}
\hline Model & R & R Square & Adjusted R Square & Extent of Relationship \\
\hline 1 & $.668^{\mathrm{a}}$ & .446 & .441 & Moderate \\
\hline
\end{tabular}

a. Predictors: (Constant), Professional Database; *alpha $<0.05$

In table 4.1 is presented the result of the analysis on the relationship between professional database and principal performance. The analysis yielded a correlation coefficient of $\mathrm{R}=0.668$. Since theRvalue is 0.668 , it is established that positive and moderate relationships exist between a professional database and principal performance in public secondary schools in Delta State.

Research Question Two: What is the relationship between staff-appraisal and principals' performance in public secondary schools in Delta State?

Table2. Simple regression analysis on the extent of the relationship between staff-appraisal and principal performance in public secondary schools

\begin{tabular}{|l|l|l|l|l|}
\hline Model & R & R Square & Adjusted R Square & Extent of Relationship \\
\hline 1 & $.637^{\text {a }}$ & .406 & .399 & Moderate \\
\hline
\end{tabular}

a. Predictors: (Constant), Staff Appraisal; *alpha $<0.05$

In table 4.2 is presented the result of the analysis on the relationship between staff-appraisal and principal performance. The analysis yielded a correlation coefficient of $R=0.637$. Since the R-value is 0.637 , it is established that positive and moderate relationships exist between staff-appraisal and principal performance in public secondary schools in Delta State.

\section{TeSt OF Null HypotheSeS}

$\mathbf{H}_{\mathbf{1}}$ : There is no significant relationship between professional database and principals' performance in public secondary schools in Delta State.

Table4.3. t-test associated with simple regression analysis on the extent of the relationship between professional database and principals' performance in public secondary schools

\begin{tabular}{|l|c|c|c|c|c|c|c|c|c|}
\hline \multirow{2}{*}{ Model } & \multicolumn{2}{|c|}{$\begin{array}{c}\text { Unstandardized } \\
\text { Coefficients }\end{array}$} & $\begin{array}{c}\text { Standardized } \\
\text { Coefficients }\end{array}$ & $\begin{array}{c}\text { t } \\
\text { value }\end{array}$ & $\begin{array}{c}\text { P- } \\
\text { value }\end{array}$ & $\begin{array}{c}\text { Alpha } \\
\text { Level }\end{array}$ & \multicolumn{2}{c|}{ Decision } \\
\cline { 3 - 7 } & B & Std. Error & \multicolumn{2}{|c|}{ Beta } & & & \\
\hline 1 & (Constant) & 13.123 & 5.605 & & 2.342 & .021 & & \\
\hline
\end{tabular}


Professional-Database and Staff-Appraisal as Correlates of Principals' Performance in Public Secondary Schools in Delta State, Nigeria

\begin{tabular}{|c|c|c|c|c|c|c|c|c|}
\hline $\begin{array}{c}\text { Professional } \\
\text { Database }\end{array}$ & 1.653 & .186 & .668 & 8.889 & .000 & \pm 1.96 & Significant \\
\hline
\end{tabular}

a. Dependent Variable: Principal Performance

Above table 4.3 shows that t-test analysis associated with simple regression yielded a T-value of 8.889. Since the t-value of 8.889 is far higher than the alpha level of 1.96 , and thus establishes that a significant relationship exists, the researcher is therefore constrained to reject the above stated null hypothesis, and therefore conclude that a significant relationship exists between professional-database and principals' performance in public secondary schools in Delta State

$\mathbf{H}_{2}$ : There is no significant relationship between staff-appraisal and principals' performance in public secondary schools in Delta State.

Table4.4. $t$-test associated with simple regression analysis on the extent of the relationship between staffappraisal and principals' performance in public secondary schools

\begin{tabular}{|c|c|c|c|c|c|c|c|c|}
\hline \multirow{2}{*}{ Model } & \multicolumn{2}{c|}{$\begin{array}{c}\text { Unstandardized } \\
\text { Coefficients }\end{array}$} & $\begin{array}{c}\text { Standardized } \\
\text { Coefficients }\end{array}$ & \multirow{2}{*}{$\begin{array}{c}\text { T } \\
\text { P- } \\
\text { value }\end{array}$} & $\begin{array}{c}\text { Alpha } \\
\text { Level }\end{array}$ & \multirow{2}{*}{ Decision } \\
\cline { 3 - 9 } & B & Std. Error & \multicolumn{2}{|c|}{ Beta } & & & \\
\hline \multirow{2}{*}{1} & (Constant) & 22.667 & 4.947 & & 4.582 & .000 & & \\
\cline { 2 - 9 } & $\begin{array}{c}\text { Staff } \\
\text { Appraisal }\end{array}$ & 1.431 & .175 & .637 & 8.177 & .000 & \pm 1.96 & Significant \\
\hline
\end{tabular}

a. Dependent Variable: Principal Performance

Above table 4.4 shows that t-test analysis associated with simple regression yielded a t-value of 8.177. Since the T-value of 8.177 is far higher than the alpha level of 1.96 critical level, the researcher is thus constrained to reject the above stated null hypothesis, and therefore conclude that a significant relationship exists between staff-appraisal and principals' performance in public secondary schools in Delta State

\section{DISCUSSION OF FINDING AND IMPLICATION}

\subsection{Professional Database and Principals' Performance in School Administration}

As already established, the regression Pearson $\mathrm{R}$ of 0.668 showed that there is a positive and moderate relationship between professional database and principals' performance. This study has shown that a professional database is instrumental in building and maintaining a professional relationship with principals. Because they regularly used their respective database to search out details of their professional colleagues to network and connect with them for different reasons, including collaboration in research work, academic partnership, and support in different areas of school administration. This study's results are in line with previous studies of Serrano et al. (2017:243), who found out that principals used information from their database to reach out to knowledgeable school administrators to discuss administration issues and make pre-arrangement for the meeting where they discussed the managerial issue of concern. Darling-Hammond et al. (2009:5) observed that such meetings often lead to mentorship relationships which some principals leveraged to learn new skills in school management practices.

This study is consistent with Etomes and Molua (2019:110). They observed that educators always need external support, adding that their experiences and capacities are often not enough to match the level of improvement the school aspires to attain. The scholar further observed that administrators need to expand their professional database and acquaintances to build social capital and social network muscles that one can leverage during professional needs. Corroborating the findings of this study, Gregoire (2009:4-5) reported that high-profile professionals who earn higher incomes had vast networks and connections across the length and breadth of their calling. However, the scholar submitted that not all people in one's database might be willing to be friendly. According to the scholar, some may even be speaking maliciously against one; nevertheless, the time and efforts invested in professional networking always produce juicy results.

This study further showed that the professional database was significantly related to principals' performance in public secondary schools in Delta State. This finding agrees with Schuck (2003:50), who remarked that a deep professional relationship takes time to build, adding that regular 
communication involving give and take to excite mutual feelings of care and compassion for each party is necessary for deepening social and professional relationships. This means that principals who want to accelerate their professional standing must be ready to keep the professional database and invest time in relationship development, building and maintenance to accelerate their career advancement.

\subsection{Staff-Appraisal and Principals' Performance in School Administration}

The regression Pearson $\mathrm{R}$ of 0.637 showed a positive and moderate relationship between staffappraisal and principals' performance. This finding has validated the idea that appraising principals to determine their performance level and assisting them in areas of difficulties in school management is associated with higher performance. This study is therefore in accord with Clifford et al. (2014:1). They observed that appraisal not only helps school managers rouse a sense of answerability for instructional effectiveness on principals. But will also serves as a vital support strategy to enable principals to acquire administrative skills.Especially when the appraisal process is designed so that trained assessors/evaluators can communicate, interact and share ideas with the appraisees (i.e., newly appointed principals) on better ways of doing specific things in schools. Therefore, this study is consistent with Aloo et al. (2017), whose study regression table showed that 52.5\% efficacy of curriculum evaluation was ascribed to instructors' work-performance appraisal, reporting further that instructors' work-performance appraisal was a strong predictor of practical curriculum evaluation.

Furthermore, the finding of this study is partly consistent and inconsistent with the results of Nielsen (2018), who reported that principals and assistant principals were divided over the impact of the appraisal process on their professional development and growth vis-a-viz instructional leadership. The scholar attributed the division to school leaders' desired to grow and become influential leaders in their school district.However, the approach with which the appraisal and evaluation were conducted could not provide the needed closer relationship they desired in terms of good interaction and proper discussions with feedbacks reports from evaluators.

This study also showed that staff-appraisal was significantly related to principals' performance in public secondary schools in Delta State. This is consistent with Aloo et al. (2017), whose findings showed a strong and positive relationship between the appraisal program and the instructor's performance. Similarly, the scatterplot interpretation showed a moderate relationship between instructors' performance appraisal and curriculum evaluation. In light of this finding, appraisal can help school administrators improve their capabilities in both technical areas of school operations and build productive relationships within an external school environment.It also allows principalsto get to know their colleagues and other experts in the field whose valuable experiences and productive discussions during appraisal processes can be of immense benefit to principals being appraised. Also, the feedback, such as value-judgment, objective criticism, encouragement, and counsels, are some of the contents of appraisal feedback prepared by external appraisers to help principals identify task areas to improve their capacities for better performance. Such feedbacks, which ought to be reliable and trusted, will enable principals to know the areas to focus more attention on professional capacity development activities

\section{CONCLUSION}

Based on the findings of the study, the researcher concludes that professional-database and staffappraisal are effective strategies for improving a principal's performance in a public secondary school in Delta State. This study also concludes that professional-database and staff-appraisal have a positive, moderate, and significant relationship with principals' performance in public secondary schools in Delta State. 


\section{RECOMMENDATIONS}

Based on the conclusion of this study, the following recommendations were made

1. Principals should learn how to keep records of their colleagues, experts, and subordinates to enable them (principals) to track their co-workers and learning partners for work-related communication.

2. The Ministry of Education should regularly appraise principals' performanceto enable them to learn from reputable experts and improve their performance in school administration.

\section{REFERENCES}

Akhtar, I. \& Cheema, K.U.R. (2014). Evaluation of principal performance in public and private sector schools. International Journal of Management \& Organizational Studies, 2(3) 24-30.

Aloo, J.O., Ajowi, J. O. \&Aloka, P.J. (2017). Influence of teacher performance appraisal on effectiveness in curriculum evaluation in Kenyan public secondary schools. Academic Journal of Interdisciplinary Studies,6(3),77-84

Asodike, J.D. \&Ogbu, T. (2014). Teacher utilization and staff appraisal in the school organization. In F. N. Obasi \& J.D. Asodike (Eds) Educational resource management (pp: 97-117). Pearl Publishers.

Asuku, M. \& Abraham, N.M. (2019). Teacher's appraisal technique practices for enhanced productivity in secondary schools in Bayelsa State, Nigeria. International Journal of Research and Innovation in Social Science, 3(8), 535-540.

Clifford, M., Hansen, U. C. \&Wraight, S. (2014). A practical guide to designing comprehensive principal evaluation systems. A tool to assist in the development of principal evaluation systems. https://files.eric.ed.gov/fulltext/ED555668.pdf

Darling-Hammond, L., Wei, R. C., Andree, A., Richardson, N., \&Orphanos, S. (2009). Professional learning in the learning profession (Technical report). National Staff Development Council. https://edpolicy. stanford.edu/sites/default/files/publications/professional-learning-learning-profession-status-reportteacher-development-us-and-abroad.pdf

Etomes, S. E. \&Molua, E L. (2019). Strategies for enhancing the productivity of secondary school teachers in the South West Region of Cameroon. Journal of Education and Learning, 8, (1),109-119

Etomes, S. M. R., Alfaya, G. E., \& García, O.M. A. (2017). Networking and professional development among teachers of Early Childhood Education. Foro de Educación, 15(23), 243-256.

Green, J. (2009). The deformation of professional formation: Managerial targets and the undermining of professional judgment. Ethics and Social Welfare, 3(2), 115-130.

Gregoire, R. (2009).Professional networking and its impact on career advancement. a study of practices, systems, and opinions of high-earning, elite professionals.Upwardly Mobile, Inc.http://www.belladomain. com/wp-content/uploads/2010/05/ effective_networker_study.pdf

Gudyzanga, E., Shumba, P. \&Wadesango, N. (2014). An analysis of the performance appraisal system in Shurugwi District Day Secondary Schools. Journal of Social Sciences, 41(3), 461-470.

Ion, I. I. \&Criveanu, M. (2016). Organizational performance - a concept that self-seeks to find itself. Annals of the „Constantin Brâncuşi, University of Târgu Jiu, Economy Series, 4. http://www.utgjiu.ro/revista/ec/ pdf/2016-04/27_Ion,\%20Criveanu.pdf

Ivanov, C.\&Avasilca, S. (2013). Performance measurement models: an analysis for measuring innovation processes performance. Procedia - Social and Behavioral Sciences 124, 397 - 404

Nielsen, J. (2018). The principal evaluation: connecting principals' evaluation of the growth and development process: A case study. Unpublisheddissertations and student research. 288. The University of Nebraska. https://digitalcommons.unl.edu/cehsedaddiss/288

O'Donnell, F.J. \& Duffy, A.H.B. (2002), Modelling design development performance, International Journal of Operations \& Production Management, 22(11)1198-1221.

Organization for Economic Cooperation and Development (OECD) (2013). The appraisal of school leaders: Fostering pedagogical leadership in schools. https://www.oecd-ilibrary.org/the-appraisal-of-schoolleaders-fostering-pedagogical-leadership-inschools_5k49dvlqj037.pdf?itemId=\%2Fcontent\%2Fcomponent\%2F9789264190658-11en\&mimeType $=$ pdf

Padzil, I., Kadir, S. A., Ayob, A. F. M., \& Arshad, M. M. (2019). Principals' acceptance of school improvement partners mentoring practice in Malaysia. International Journal of Academic Research in Business and Social Sciences, 9(11), 1446-1461. 
Professional-Database and Staff-Appraisal as Correlates of Principals' Performance in Public Secondary Schools in Delta State, Nigeria

Samsonowa, T. (2012). Industrial research performance management key performance indicators in the ICT industry. Physica-Verlag Heidelberg.

Stronge, J. H. (2013). Principal evaluation: A framework for principal evaluation. Alexandria, VA: ASCD.

Whittaker, S., and Sidner, C. (1996). Email overload: Exploring personal information management of email. In CHI'96. New York, ACM, 276-283. http://students.lti.cs .cmu.edu/11899/files/cp3a-whittaker-sidner.pdf

Citation: EBUNU, Akpofure. Anna. "Professional-Database and Staff-Appraisal as Correlates of Principals' Performance in Public Secondary Schools in Delta State, Nigeria” International Journal of Humanities Social Sciences and Education (IJHSSE), vol 8, no. 7, 2021, pp. 202-210. doi: https://doi.org/10.20431/23490381.0807023.

Copyright: (C) 2021 Authors. This is an open-access article distributed under the terms of the Creative Commons Attribution License, which permits unrestricted use, distribution, and reproduction in any medium, provided the original author and source are credited. 